\title{
The effect of two types of stretching on flexibility in selected joints in youth soccer players
}

\author{
Andrea Mahrováa,*, Pavel Hráský1, František Zahálka ${ }^{1}$, and Petr Požárek ${ }^{2}$ \\ ${ }^{I}$ Sport Research Centre, Faculty of Physical Education and Sports, Charles University in Prague, Prague, Czech Republic; \\ and ${ }^{2}$ Faculty of Education, University of South Bohemia, České Budějovice, Czech Republic
}

Copyright: () 2014 A. Mahrová et al. This is an open access article licensed under the Creative Commons Attribution License (http:// creativecommons.org/licenses/by/4.0/).

\begin{abstract}
Background: The nature of soccer causes overloading of certain muscles and muscle groups that are most often involved in typical training activities of players. Often the absence of additional leisure-time activities typical for children and adolescents leads to an increased risk of muscle imbalance. Objective: We were interested in the occurrence of muscle imbalance, specifically an occurrence of muscle shortening and limited flexibility of the spine as well as decreased range of motion (ROM) in selected joints among young soccer players. Methods: The players were randomly selected to take part in the study. Twelve young soccer players took part in the first group and thirteen in the second group (age 13 years, body weight $40.5 \pm 3.9$ vs. $41.5 \pm 7.8 \mathrm{~kg}$, height $150.0 \pm 5.0 \mathrm{vs.} 153.0 \pm 9.8 \mathrm{~cm}$ ). The first team performed only static stretching exercises at the end of the training session and the other team performed, except for static stretching, also dynamic stretching exercises always at the beginning of the training session. The effect of the stretching program on range of motion in chosen joints was assessed by $2 \times 2$ repeated-measures ANOVA (stretching methods $\times$ time). The statistical significance of $\alpha$-level was set to .05 and partial $\eta_{p}{ }^{2}$. Results: Pre-test measurements revealed an occurrence of muscle shortening and limited ROM of the spine and selected joints mostly in the pelvis and lower limbs in all study participants. Comparison of ROM in selected joints between pre-test and post-test in program including both static and dynamic stretching showed significant increase of left hip during flexion $\left(p=.03, \eta_{\mathrm{p}}{ }^{2}=.20\right)$. The program with only static stretching showed significant decrease the ROM of ankle plantar flexion $\left(p=.04, \eta_{\mathrm{p}}{ }^{2}=.18\right)$. We did not find any significant difference between stretching programs on ROM. As for muscle shortening, both side improvements (higher number of subjects with no muscle shortening) were found in the following muscle or muscle groups - $\mathrm{m}$. trapesius, $\mathrm{m}$. pectoralis major, $\mathrm{m}$. rectus femoris, $\mathrm{m}$. tensor fasciae latae, knee flexors and $\mathrm{m}$. triceps surae. Improvements were also observed in group 1, but corrections were only asymmetrical. Conclusions: The stretching program in the group of soccer players could lead to increase of range of motion in some joints after a special program. It could serve as protection from muscle imbalance and lower limb injuries.
\end{abstract}

Keywords: muscle imbalance, muscle shortening, joint mobility, stretching, soccer

\section{Introduction}

When the physical load is not sufficiently compensated, especially among highly specialized athletes, it can result in one-sided overload of the movement system, which may consequently lead to severe dysfunctions of the system.

Although all physical abilities such as coordination, speed, strength, endurance or flexibility are important for soccer players, each age category has a preferred

\footnotetext{
* Address for correspondence: Andrea Mahrová, Sport Research Centre, Faculty of Physical Education and Sport, Charles University, José Martího 31, 16252 Praha 6, Czech Republic. E-mail:mahrova@centrum.cz
}

physical ability which is being developed. Coordination is developed at first, then speed which further followed by the development of strength, endurance and flexibility (Dovalil et al., 2002). All physical abilities are affected by the muscle system, specifically by the quality and function of muscle fibres. Overload of the trunk, pelvis and lower limbs is often diagnosed among soccer players due to relatively monotonous load and lack of supplementary physical activities. According to Kutáč and Gajda (2006) this is the result of an intensive loading in the aforementioned parts of the body during training. Training of soccer players often include repeated skills and motor actions such as running, fast direction changes, or various ways of shooting and passing. 
This asymmetry together with a lack of compensation for the monotonous load may result in overloads of axial and joint structures caused by one-sided muscle hypertrophy and limited joint mobility. Overloaded muscles and muscle groups react to increased asymmetric load without compensation that lead to increased muscle tonus and muscle shortenings. (Lewit, 1996).

One-sided overload activity may firstly cause some kinds of deviations of body axis and functional changes in spine and joints (e.g. functional blocks of spine, functional scoliosis). Secondly, due to repeated loading, this may lead to serious structural changes or destruction of cartilage and their faster abrasion (Adamčák, 2000; Lewit, 1996; Véle, 1997).

In addition small injuries - micro-traumas, which are ignored for a long time because of their minimal effect on physical fitness and slight subjective symptoms, may appear in repeatedly overloaded muscles without necessary compensation. The most affected are the lower limbs. Also local changes such as light bleeding and ruptures of muscle fibers. Shortened muscle is less resistant to load and more prone to injury and decrease the reaction time (Adamčák, 2005; Arnason, Andersen, Holme, Engebretsen, \& Bahr, 2008; Friery, 2008; Volpi, Melegati, Tornese, \& Bandi, 2004; Wong $\&$ Hong, 2005). It results in predispositions for muscle imbalance and overall dysfunction of the movement system. Muscle imbalance is often accompanied by pain in the damaged segment, reduced physical fitness, coordination disorders and modification of movement patterns.

So called upper and lower cross syndromes are the most commonly occurring muscular imbalances in football. Both syndromes are caused by imbalance between phasic and tonic muscles (Bursová, Votík, \& Zálabák, 2003).

Fixations of motor stereotypes of a movement performance begin in childhood. Movement performance is influenced by every change that occurs in the movement system. If this change is combined with a painful reaction, it may activate reflex reaction not only in the particular segment, but in segments more remote from the focal point (Trojan, Druga, Pfeiffer, \& Votava, 1996). Furthermore, incorrectly coded and fixed motor stereotypes are not economic for an athlete's organism. In some cases, underestimation and lack of load compensation may lead to irreversible changes in the movement system and even end athlete's professional career (Cingálková, Bunc, \& Cingálek, 2001).

Problems and pain in the lumbar spine and hip joints, muscle injuries of lower limbs or unstable knee and ankle joints are often present among talented children specializing in soccer (Šrámková \& Votík, 2010).
Compensation exercises focused on the correction of muscle imbalance are inevitable in any training process from early childhood (Adamčák, 2000; Kutáč \& Gajda, 2006; Peterson, Renström, \& Grana, 1986). According to Bunc (2006), it is possible to develop an "addiction" to physical activity. The most sensitive period of growth is between 1-3 and 6-8 years of age. This period is very important to predict the athletes' performance in the following decades. Factors such as sets of compensation exercises, ergonomics of a work place, and used surface play an important role in prevention of dysfunctions of the movement system in actively competing children and adolescents (Brügger, 1993).

Compensation exercises consist of various set of simple exercises in specific positions which can be effectively modified by the use of different kinds of equipment. All exercises should always consider individual's current functional status of the movement system (Bursová, 2005).

Stretching is one of the famous compensation exercises based on muscle extension and increased ligament tension. It optimizes the process in which the individual learns, practices and performs various motor skills - it deepens movement perception, reduces risk of injury, reduces muscle tension and muscle soreness, etc. Stretching techniques, if performed correctly according to recommendations, increase the range of motion - individual's flexibility, e.g. ability to move muscles and joints in their full range (Alter, 1999). The choice of the stretching technique (active, passive, and combination of both, with neuromuscular facilitation) depends on the aim that we want to achieve, on the individual's current health conditions and environment (Houglum, 2001).

The purpose of this study was to compare the effects of using only a static stretching program with a combination of dynamic and static stretching program on flexibility in the selected joints, mainly of lower extremities.

The stretching intervention program was designed to influence existing muscle imbalances and to regulate spine and joint mobility.

\section{Methods}

\section{Participants' characteristics}

The study sample consisted of 25 boys, youth soccer players of two teams - SK Dynamo České Budějovice (group 1, $N=12$ ) and SK Slavia Praha (group 2, $N=13$ ). Both teams took part in the F1A competition of the Czech soccer league in the category of youth players U-13. Prior to the study, the players, as well as 
their parents, were fully informed about the goal and methods of the measurements and they provided their written consent. The study was approved by the Ethical Committee of the Faculty of Physical Education and Sports, Charles University in Prague and conformed to the Declaration of Helsinki regarding the use of human subjects.

Training load of both groups was the same. Soccer players performed minimal other leisure-time sport activities. No player had an injury which could significantly affect data collection and intervention.

\section{Assessment of body composition}

The data identifying participants' body composition (BC) were recorded under identical conditions, in the morning hours, at the beginning of the pre-test and post-test measurements. BC measurement by means of a bioimpedance method was carried out under standard conditions according to BIA guidelines (Kyle et al., 2004). Just before the measurement, the current body weight (BW) of the participants was measured on an electronic digital scale (seca 769, seca, Hamburg, Germany) with a precision of $0.1 \mathrm{~kg}$, and the body height $(\mathrm{BH})$ of the participants in an upright position was measured with the precision of full $\mathrm{mm}$ by means of digital stadiometer (seca 242, seca, Hamburg, Germany). The body bioimpedance was determined with the phase sensitive whole body tetrapolar bioimpedance analyzer BIA $2000 \mathrm{M}$ device (Data Input GmbH, Pöcking, Germany) which works on four frequencies $(1,5,50$ and $100 \mathrm{kHz})$ and is compatible with the NUTRI 4 software. The measurement was carried out in a prone position and participants' extremities were abducted. Four electrodes were placed on the proximal and dorsal surface of the right hand and right foot. The measurement itself took about $45 \mathrm{~s}$. The contact resistance between the electrode surface and the skin did not exceed 250 Ohms. Information about the measurement's reliability and the validity of this method in the general population has been published by Dittmar
(2003). We were particularly interested in the amount of lean body mass (LBM) and the percentage of body fat (BF). Basic anthropometric characteristics of both baseline and outcome measurements of both groups are presented in Table 1.

\section{Evaluation of muscle shortenings}

The methodology presented in the strength test according to Janda (1996) was used to examine muscle shortenings. Attention was focused on muscle groups that are loaded in soccer the most and tend to shorten. Apart from muscles of lower limbs, assessment included selected muscles of the neck and trunk which are associated with posture maintenance and related motion. Selected muscles and muscle groups included - m. trapesius (upper part); m. pectoralis major (upward part); flexors of the hip joint (m. iliopsoas; m. rectus femoris; m. tensor fasciae latae); hip joint adductors; flexors of the knee joint ( $\mathrm{m}$. biceps femoris; $\mathrm{m}$. semitendinosus; $\mathrm{m}$. semimembranosus) and $\mathrm{m}$. triceps surae. The 3 -point scale, with values $0,1,2(0=$ no shortening, $1=$ medium shortening, 2 = significant shortening) was used to evaluate the magnitude of muscle shortenings. To ensure good inter-rater reliability, the assessment was done repeatedly by the same physiotherapist.

\section{Evaluation of joint mobility}

Spine mobility was assessed by Thomayer's test according to Gúth (1994). A minus sign (-) was assigned to insufficient range of motion, zero (0) was assigned to the standard range and finally plus sign $(+)$ was assigned to above standard range of motion.

Joint mobility was assessed by 2D video-graphic kinematic analysis (Janura \& Zahálka, 2004). Tested persons were recorded by a video camera SONY HDRHC9 (Sony, Japan) with frame rate 50 half frames per second and consequently captured to PC. The format was Mini-DV with overall field $575 \times 720$ pixels. Width of recorded view was $1.75 \mathrm{~m}$ providing $0.3 \mathrm{~mm}$ error of reconstruction. Joints of interest were marked by

Table 1

Basic anthropometric characteristics of group 1 and group 2 - pre-test and post-test examination tests

\begin{tabular}{|c|c|c|c|c|c|c|c|c|}
\hline \multirow[b]{3}{*}{ Variable } & \multicolumn{4}{|c|}{ Group $1(N=12)$} & \multicolumn{4}{|c|}{ Group $2(N=13)$} \\
\hline & \multicolumn{2}{|c|}{ Pre-test } & \multicolumn{2}{|c|}{ Post-test } & \multicolumn{2}{|c|}{ Pre-test } & \multicolumn{2}{|c|}{ Post-test } \\
\hline & $M$ & $S D$ & $M$ & $S D$ & $M$ & $S D$ & $M$ & $S D$ \\
\hline Age (years) & 13.0 & 0.0 & 13.0 & 0.0 & 13.0 & 0.0 & 13.0 & 0.0 \\
\hline Body weight (kg) & 40.5 & 3.9 & 44.4 & 4.6 & 41.5 & 7.8 & 43.5 & 8.5 \\
\hline Body height $(\mathrm{cm})$ & 150.0 & 5.0 & 155.0 & 7.8 & 153.0 & 9.8 & 157.0 & 10.5 \\
\hline Body fat (\%) & 8.3 & 1.4 & 9.0 & 1.3 & 8.3 & 1.1 & 7.8 & 1.5 \\
\hline Lean body mass (kg) & 37.9 & 3.2 & 39.9 & 4.7 & 37.7 & 7.3 & 41.1 & 7.7 \\
\hline
\end{tabular}




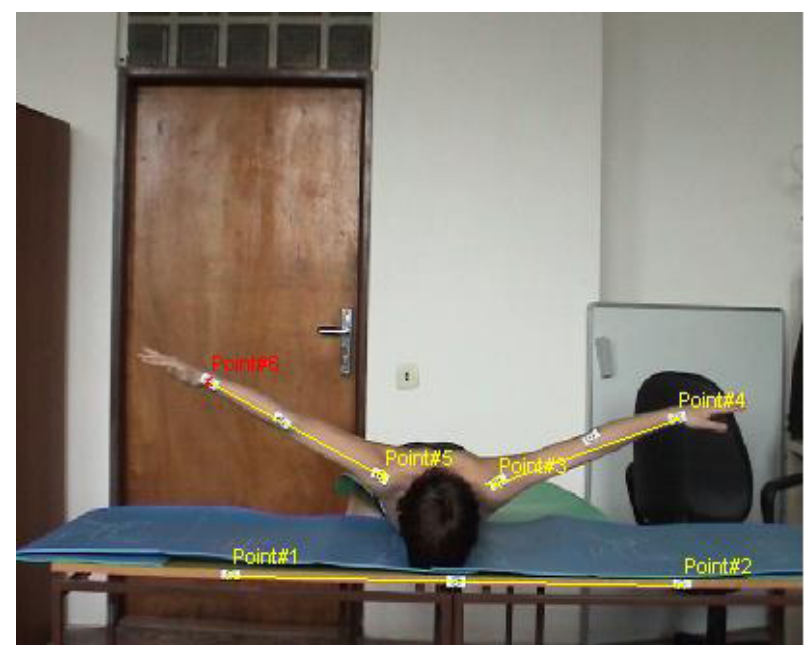

Figure 1. Illustration of markers on palpatory identifiable places representing important joints

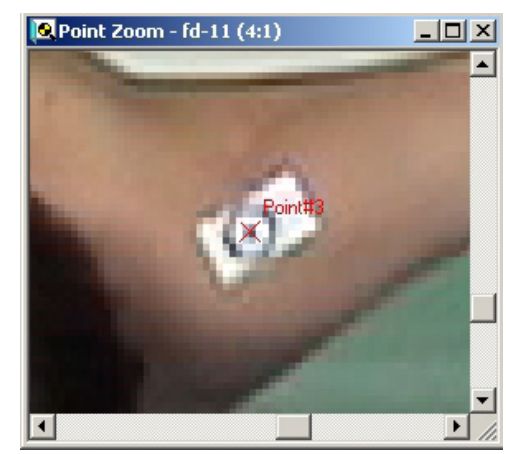

Figure 2. Detail of a marker

palpation. Accuracy of estimation of the centre of the marker was $1 \mathrm{~mm}$ (Figure 1,2). For evaluation of marker position at selected frame the software TemaBio 2.3. (Image Systems, Linköping, Sweden) was used.

Range of motion in joints (ROM) was always assessed on both sides. The assessed joints and movements included: hip joint - flexion, ankle joint - dorsal and plantar flexion (according to test rules - only in dominant side), shoulder joint - extension in horizontal abduction. These joints and movements were chosen because of their association to testing positions of muscles shortening around chest muscles, knee flexors, hip extensors and ankle flexors. Initial positions for testing ankle and shoulder joints and the manner of movement were selected according to Nováková (1994) and initial position of the hip joints was tested according to Janda and Pavlů (1993) and Rychlíková (2002). Tested joints were marked by visible markers. The movement performance was recorded by the camera system. Data were analysed according to population standards by Janda and Pavlů (1993) and Rychlíková (2002). To evaluate range of motion of hip joint flexion, a modified test and standards for assessment according to Janda (1981) with expanded knee joint on the tested limb was used.

\section{Stretching program}

The stretching program lasted six months and involved all phases of training and playing process (transition, preparatory, pre-competition and competition phase). Baseline and outcome measurements were assessed in the competition phase.

The stretching program was composed of the two sets of exercises performed by group 1 and group 2 . Both of the sets consisted of static stretching exercises. In addition the group 2 performed the dynamic stretching program including relaxing (mobilization) exercises for spine and joints of upper and lower limbs, which were accompanied by short dynamic stretching of the examined muscles and muscle groups. The exercises were performed mainly in standing position and while walking. Walking, jumping or running a few steps was inserted between particular stretching exercises. Holding in the stretch positions and rests between particular sets were not longer than $5 \mathrm{~s}$. Total time of the stretching exercise sessions in both groups was 10-15 min, e.g. 40-65 min a week.

\section{Statistical analysis}

We used the experimental design study with two groups of participants. Means and standard deviations were used to characterise the groups' tested variables (Table 4). The normality for all variables was tested by one sample Kolmogorov-Smirnov goodness of fit. The effect of stretching program on range of motion in chosen joints was assessed by $2 \times 2$ repeated-measures ANOVA (stretching methods $\times$ time). The statistical significance of $\alpha$-level was set to .05 and partial $\eta_{p}{ }^{2}$ was used to assess the percentage of explained variance (ROM hips, ankles) by the factors. The effect size $\left(\eta_{\mathrm{p}}{ }^{2}\right)$ is minimum with $\eta_{\mathrm{p}}{ }^{2}=.04$, moderate $\eta_{\mathrm{p}}{ }^{2}=.25$ and strong with $\eta_{p}{ }^{2}=.64$ (Ferguson, 2009). All statistics were computed by SPSS for Windows (Version 11.0; SPSS Inc., Chicago, IL, USA).

\section{Results}

\section{Muscle shortenings}

Examination of pre-test data of muscle shortenings in group 1 provided evidence that shortenings were present in all examined muscles except for the hip joint adductors. Shortenings were also manifested in different stages. For details see Table 2.

Post-test data after the static stretching program in the group 1 showed improvements in shortening 
of following muscles $-\mathrm{m}$. trapesius on both sides, $\mathrm{m}$. iliopsoas on the left side, $\mathrm{m}$. rectus femoris on the right side, $\mathrm{m}$. tensor fasciae latae on both sides, knee flexors on both sides and $\mathrm{m}$. triceps surae on the right side. On the other hand, further worsening of shortening was observed in $\mathrm{m}$. pectoralis major on both sides and $\mathrm{m}$. triceps surae on the left side.

Pre-test measurements of muscle shortening in the group 2 proved that all examined muscles, apart from hip joint adductors, were shortened in different stages. For details see Table 3.

Similarly to the group 1, post-test examination after the combination of dynamic and static stretching program in the group 2 showed improvements in muscles shortenings in the following muscles $-\mathrm{m}$. trapesius on both sides, $\mathrm{m}$. pectoralis major on both sides, m. rectus femoris on both sides, $m$. tensor fasciae latae on both sides, knee flexors on both sides and $m$. triceps surae on both sides, too. Only in $\mathrm{m}$. iliopsoas on both sides was found even more shortening after the dynamic stretching program.

\section{Spine mobility - Thomayer's test}

Limited range of motion in spinal mobility was found during pre-test measurements in $75 \%$ of the participants in the group 1 and in $54 \%$ of the participants in the group $2(M \pm \mathrm{SD}$ : group 1: $-3.0 \pm 3.4 \mathrm{~cm}$; group 2: $-4.0 \pm 6.4 \mathrm{~cm})$.

Post-test measurements showed improved spine mobility in both groups. In the group 1 the percentage occurrence of individuals with limited range of motion was reduced to $17 \%$ and in the group 2 to $38 \%$ (mean $\pm \mathrm{SD}$ : group 1: $-2.0 \pm 3.4 \mathrm{~cm}$; group 2: $-1.0 \pm 6.0 \mathrm{~cm})$.

\section{Joint mobility - range of motion in selected joints}

Changes of joint flexibility between pre-test and posttest in interaction with stretching program were not statistically significant (Table 4). The participants in the group 1 performed greater ROM in ankle during dorsal flexion then participants in the group 2. We found significant changes in pre-test and post-test in range of motion for ankle plantar flexion $(p=.04$, $\left.\eta_{\mathrm{p}}{ }^{2}=.18\right)$ after the combination of dynamic and static stretching. Further, in group 2 we found that the range of motion of left hip in flexion increased significantly $\left(p=.03, \eta_{\mathrm{p}}^{2}=.20\right)$.

Range of motion of measured joints of both groups influenced by stretching is presented in Table 4.

ROM Results for group 1 provided evidence that the average range of motion in ankle in dorsal flexion reach population standards (Janda \& Pavlů, 1998; Rychlíková, 2002) in both pre-test and posttest measurements. Above standard values in both measurements of plantar flexion were observed in all participants from group 1. After the stretching program, range of joint mobility in ankle joint remained within standard or above standard values, but at the same time further decline in the range of motion in both tests was observed in group 1. In the same group were observed values below average in both pre-test and post-test measurements in hip joint flexion on both sides. After the stretching program, 5 participants (38\%) achieved improved range of motion of the hip joint on the right and 9 participants $(75 \%)$ on the left side. However reached values were still below average.

In the majority of cases from the group 1, range of motion during extension in horizontal abduction of shoulder joints was average and above average on both sides in both pre-test as well as post-test measurements. After the stretching program, improvement of range of motion appeared in 8 participants $(67 \%)$ on the right side and in 9 participants $(75 \%)$ on the left side.

Results of ranges of motion of group 2 provided evidence that the average range of motion in ankle joint dorsal flexion reached population standards in both pre-test and post-test measurements. Above average values were observed in plantar flexion for all participants in both measurements. After the stretching program, ranges of motion in ankle remained within population standards or above average. But at the same time we noticed worsened range of motion in both dorsal and plantar flexions.

Below average values were observed in the range of motion in flexion of the hip joint again on both pretest and post-test measurements. After the stretching program, 7 participants (54\%) improved their range of motion on the right side and 9 participants (70\%) on the left side from, however, values were still below average.

Similarly, extension in horizontal abduction of shoulder joint reached average values of range of motion on both sides in all participants in both measurements. After the stretching program, 8 participants (67\%) improved their range of motion on the right side and 9 participants $(75 \%)$ on the left side.

\section{Discussion}

The stated problems have been constantly discussed by professionals (teachers and coaches) and they have been a part of professional soccer coaches' education. Despite this fact, only a limited number of research studies focused on the functional status of the movement system of youth soccer players, ways to compensate muscle imbalance and timing of stretching exercises within training sessions were found in the available literature (Adamčák, 2000; De Castro, 

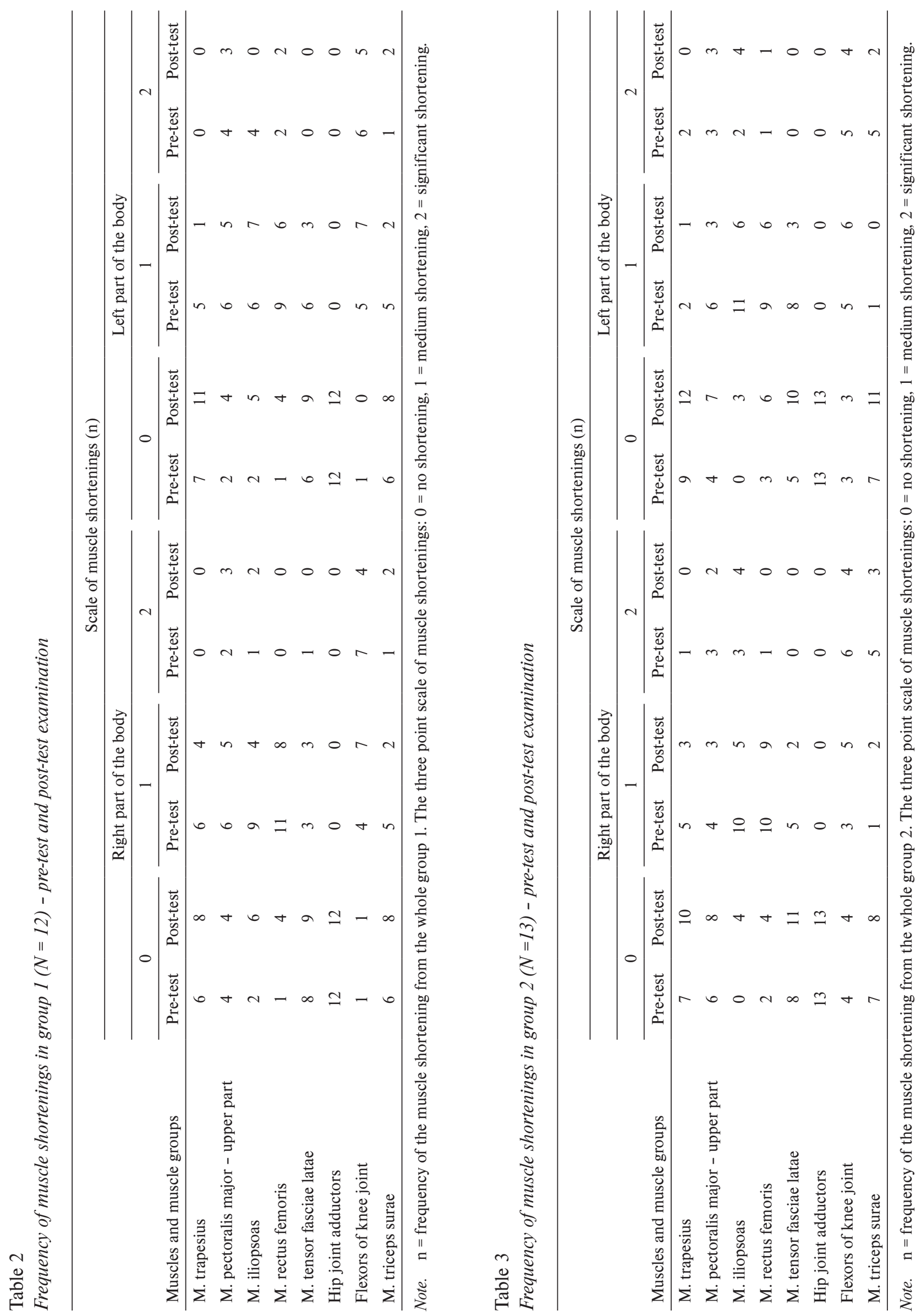
Table 4

Comparison of ranges of motion (degrees) in selected joints between different intervention

\begin{tabular}{|c|c|c|c|c|c|c|c|c|}
\hline \multirow[b]{3}{*}{ Joint - movement } & \multirow[b]{3}{*}{ Intervention } & \multicolumn{4}{|c|}{ Descriptive statistics of ROM (degrees) } & & & \\
\hline & & \multicolumn{2}{|c|}{ Pre-test } & \multicolumn{2}{|c|}{ Post-test } & \multicolumn{3}{|c|}{ Statistical analyses } \\
\hline & & $M$ & $S D$ & $M$ & $S D$ & $F$ & $p$ & $\eta_{p}{ }^{2}$ \\
\hline \multirow[t]{2}{*}{ Ankle DF } & $\mathrm{S}$ & 27.0 & 4.9 & 23.6 & 9.8 & 0.02 & .89 & $<.001$ \\
\hline & $\mathrm{S}+\mathrm{D}$ & 23.7 & 8.1 & 20.8 & 3.9 & & & \\
\hline \multirow[t]{2}{*}{ Ankle PF } & S & 70.7 & 4.7 & 65.1 & 9.0 & 3.95 & .06 & .15 \\
\hline & $\mathrm{S}+\mathrm{D}$ & 63.6 & 5.4 & 63.3 & 5.5 & & & \\
\hline \multirow[t]{2}{*}{ Hip FL right } & $S$ & 68.7 & 6.7 & 67.9 & 10.9 & 0.02 & .88 & $<.001$ \\
\hline & $\mathrm{S}+\mathrm{D}$ & 71.6 & 7.5 & 71.3 & 6.7 & & & \\
\hline \multirow[t]{2}{*}{ Hip FL left } & S & 67.3 & 6.5 & 70.5 & 5.1 & 0.01 & .91 & $<.001$ \\
\hline & $\mathrm{S}+\mathrm{D}$ & 67.6 & 9.1 & 71.1 & 9.8 & & & \\
\hline \multirow[t]{2}{*}{ Shoulder EXTHA right } & S & 33.0 & 16.3 & 37.4 & 10.3 & 1.23 & .28 & .05 \\
\hline & $\mathrm{S}+\mathrm{D}$ & 39.9 & 15.8 & 38.2 & 16.4 & & & \\
\hline \multirow[t]{2}{*}{ Shoulder EXTHA left } & $S$ & 32.9 & 12.7 & 39.8 & 10.4 & 3.22 & .09 & .12 \\
\hline & $\mathrm{S}+\mathrm{D}$ & 39.9 & 15.3 & 38.2 & 17.7 & & & \\
\hline
\end{tabular}

Note. $\mathrm{ROM}=$ range of motion. $\mathrm{DF}=$ dorsal flexion, $\mathrm{PF}=$ plantar flexion, $\mathrm{FL}=$ flexion, $\mathrm{EXTHA}=$ extension in horizontal abduction, $\mathrm{S}=$ static stretching (data of the group 1), $\mathrm{S}+\mathrm{D}=$ static and dynamic stretching (data of the group 2 ). $F=$ Fisher's $F$ ratio, $\eta_{\mathrm{p}}{ }^{2}=$ partial Eta Squared.

Machado, Scaramussa, \& Gomes, 2013; Kutáč \& Gajda, 2006; Theodorou, Galazoulas, Zakas, Vergou, \& Vamvakoudis, 2005).

In general a positive effect of stretching techniques on (1) compensation of overloaded or monotonously loaded muscles, (2) reduction of muscle shortenings, and (3) elimination of muscle imbalances (in combination with strength developing techniques) is well established. Thus, inclusion of stretching exercises in training process of athletes of every age category would be expected. In our study it was hypothesized, that the status of joint and muscle system of youth soccer players would be comparable with population standards, or it would match the norms after the stretching program. Our hypothesis was supported by Šrámková and Votík (2010) who studied issues of muscular imbalances and means of imbalance prevention as well as correction within the same age group. The research team discovered that application of specialized gymnastic training which requires good spine flexibility in all directions can correct developed muscle imbalances. Both constant corrections and increased performance of trunk flexion during training unit and at home training can positively affect functional status of movement system.

Both examined groups showed muscle shortenings of different stages, apart from hip joint adductors without side asymmetries, in both measurements.
Changes of joint flexibility between pre-test and posttest in interaction with the stretching program were not statistically significant. Participants in the group 1 performed better in ankle during dorsal flexion then participants in the group 2. We can discuss the changes influenced by this age. It could be caused by the small sample and by growing periods.

In the current scientific literature we did not find any study dealing with a similar problem in youth soccer players so our results cannot be compared to existing data. However, a few similar studies may be mentioned. Kutáč and Gajda (2006) and Adamčák (2000) dealt with the stated problem in adolescent soccer players. Kutáč and Gajda (2006) studied muscle shortenings in loaded muscles of lower limbs and the trunk (knee flexors, m. iliopsoas, m. pectoralis major and $\mathrm{m}$. rectus abdominis) in a group of soccer players between 16-18 years of age from different performance categories. The most shortened muscles were knee flexors on both sides (more on the left side) in 22 out of 24 players of the lowest performance category. Interestingly the highest occurrence of muscle shortenings was found in players of the lowest performance category which includes city championship and city competition. They achieved worse results in tests of muscle imbalance despite the fact that these players train less than league players or players competing in 
regional tournaments. A logical explanation of these results was offered at the end of the study, specifically in a summary of overall time players spend training and performing compensation activities in the training session. The lowest performance group stated zero time for compensation activities in training. Adamčák (2000) focused mainly on muscle shortenings in lower limbs in 16 year old soccer players $(N=22)$, where the highest stage of muscle shortenings was measured in knee flexors $-90.9 \%$ on the right side and $81.8 \%$ on the left side. The next most shortened muscles or muscle groups were $\mathrm{m}$. tensor fasciae latae, $\mathrm{m}$. rectus femoris, hip joint adductors, $\mathrm{m}$. iliopsoas and $\mathrm{m}$. soleus.

The study of Malátová and Matějková (2011) was focused on muscle imbalance among soccer players between 21-33 years of age. The greatest improvement was achieved by compensatory exercise in the muscle group responsible for hip flexion. Shortening of lumbar muscles, hamstrings and muscles in the back of the neck was also successfully affected. Abdominal muscles were strengthened.

Spine mobility in participants of both groups was limited in the baseline measurements. However improvements were observed after the intervention for both groups. Adamčák (2000) found that the range of motion of all examined joints and spine was similar to the values of healthy population. In some case even slight hyper-mobility was present.

Limited range of motion in hip flexion on both sides is closely associated with muscle shortenings found in knee flexors. Changes in other study variables were not statistically or clinically significant. Also no statistically or clinically significant changes were observed in interaction time (pre-test, post-test) and the stretching programs. We did not find any effect of the stretching programs.

The presented shortenings, mainly of lower limbs (hip joint flexors and knee flexors), and limited range of motion, especially in hip joints, suggest that inclusion of stretching techniques into training sessions of youth soccer players is needed. In order to achieve the most benefits, the stretching program should be accompanied by strengthening exercises for weakened muscles.

The stretching method was chosen as the technique for compensation of sport load in the present study because its benefits for all kind of sports are well documented (Aguilar et al., 2012; Amiri-Khorasani, 2013; Behm \& Chaouachi, 2011; Magnusson \& Renström, 2006; Nédélec et al., 2012; Rogan, Wüst, Schwitter, \& Schmidtbleicher, 2013; Yuktasir \& Kaya, 2009; Zakas, Doganis, Galazoulas, \& Vamvakoudis, 2006; Zakas, Grammatikopoulou, Zakas, Zahariadis, \& Vamvakoudis, 2006). The benefits include: (1) improvements in the range of joint motion, (2) prevention of muscle injuries and (3) improvements of physical performance. This technique does not require demanding space and material. The choice of the stretching method depends on one's fitness capacity and abilities, on the situation where the stretching is performed, and on goals that an athlete wants to achieve.

The technique of static stretching is according to Alter (1999) one of the safest in terms of muscle injury, because all the movements, which are performed during muscle elongation, are slow and controlled. Alter (1999) recommends that stretching should be performed after the main part of the training session. Kovacs (2006) warns that the static form of stretching is often used within warm-up before sport activities, in spite of the fact that nowadays there are still no available studies which would confirm, that it improves fitness or supports prevention from injury. This is the reason why the static stretching program was performed during the final part of the training session. According to Little and Williams (2006) static stretching does not appear to be detrimental to high-speed performance when included in a warm-up for professional soccer players. However, dynamic stretching during the warmup was most effective as preparation for subsequent high-speed performance.

Amiri-Khorasani, Abu Osman, and Yusof (2011) recommended professional soccer players to incorporate into warm-ups dynamic stretching exercises of the hip joint, hence increasing the chances of scoring and injury prevention during soccer games.

From a practical point of view, the aim of dynamic stretching is to stimulate muscles before sport activities by short repeated stretches and, at the same time, to offer a relaxation for the joints of the most loaded body parts. The goal of static stretching after physical activity is to relax muscles by impulses from the Golgi tendon organs and to restore original length in loaded muscles.

The present study support previous findings and available knowledge. The results provided evidence that group 2 which performed both static and dynamic stretching at the beginning of the training session gained more significant improvements (both percentage and symmetric decrease in muscle shortenings). Similar results were found in spine and joint mobility in the group 2. Group 1 improved after the stretching program as well but the improvements were less significant.

In terms of demands on management of both methods and abilities to control the performance, we expected that higher decrease of muscle shortenings and increase in range of motion would be in the group 1 only with the static stretching program. However, 
results showed more significant improvements in the group 2 with combination of dynamic and static stretching programs. Analysis of training sessions of both groups showed some differences in a training organization. Time might be one of the factors responsible for the study results. The stretching program in group 1 may not have had enough time. Group 1 was influenced by the bus transport to the place of training session. It was not possibility to stay there a longer time. The second group commuted to training sessions individually. Another factor might be a coach (covariate human factor). There was a requirement that in both groups there should be two coaches during stretching phases of training sessions. It was always the case for group 2, but not for the group 1 .

We concluded that different results in one group would be influenced by the personality of the coach or the number of coaches. In our case, one coach did not manage to correct performance of particular exercises enough and therefore incorrect muscle stretching could have been performed. A similar situation is described by Kutáč and Gajda (2006), who emphasize the importance of the quality and professionalism of training process management and, of course, the importance of the time needed for stretching exercises so the stretching program is the most beneficial for desired compensation of muscle imbalances. In terms of the time necessary for compensation exercises, the authors suggest that $15 \mathrm{~min}$ from a 90 min training session is not sufficient. This fact was also confirmed by Fajfer (1990). Fajfer (1990) suggests at least 20 min of stretching for successful compensation within one training session.

For the future studies we would recommend to include a control group and only one intervention group as opposed to two. Also the duration of the stretching program could be extended. In addition it would be desirable to include one extra control assessment of the movement system status after the end of the study, perhaps few weeks later, to make sure that coaches are still including a stretching program into training sessions.

\section{Conclusions}

The results detected some muscle imbalance in our team of youth soccer players. Muscle imbalance and related slight range of motion of the spine and joints was observed particularly in hip and knee joints flexors. The stretching program that included dynamic components at the beginning of training sessions (performed by group 2) seems to lead to a decrease of muscle shortenings. It could be use for prevention device to decrease the injury possibilities in older years of soccer player history.

One of the reasons is a revealed presence of significant muscle shortenings and limited joint mobility already in youth soccer players.

\section{Acknowledgment}

The study was supported by research project 0021620864 "Active lifestyle in biosocial context" funded by the Ministry of Education, Youth and Sports and by the grant project of the Czech Science Foundation number P407-12-0166.

\section{References}

Adamčák, Š. (2000). Funkčné svalové poruchy u mladých futbalistov a možnosti ich odstraňovania [Functional muscle disorders in young soccer players and their removal options]. Telesná výchova a šport, 10(4), 27-30.

Adamčák, Š. (2005). Využitie strečingu v pohybovom režime žiakov základnej školy [Use of the stretching mode in the motion of elementary school pupils]. Telesná výchova a šport, 15(1), 13-15.

Aguilar, A. J., Distefano, L. J., Brown, C. N., Herman, D. C., Guskiewicz, K. M., \& Padua, D. A. (2012). A dynamic warm-up model increases quadriceps strength and hamstring flexibility. Journal of Strength and Conditioning Research, 26, 1130-1141.

Alter, M. J. (1999). Strečink: 311 protahovacích cviků pro 41 sportu [Sport Stretch: 311 stretches for 41 sports] (V. Janda \& T. Alfödi, Trans.). Praha: Grada.

Amiri-Khorasani, M. (2013). Kinematics analysis: The acute effect of different stretching methods on dynamic range of motion of lower extremity joints during soccer instep kicking. International Journal of Performance Analysis in Sport, 13, 190-199.

Amiri-Khorasani, M., Abu Osman, N. A., \& Yusof, A. (2011). Acute effect of static and dynamic stretching on hip dynamic range of motion during instep kicking in professional soccer player. Journal of Strength and Conditioning Research, 25, 1647-1652.

Arnason, A., Andersen, T. E., Holme, I., Engebretsen, L., \& Bahr, R. (2008). Prevention of hamstring strains in elite soccer: an intervention study. Scandinavian Journal of Medicine \& Science in Sports, 18, 40-48.

Behm, D., \& Chaouachi, A. (2011). A review of the acute effects of static and dynamic stretching on performance. European Journal of Applied Physiology, 111, 2633-2651.

Brügger, A. (1993). Kinesiologické aspekty omezení funkce při pohybu a držení těla [Kinesiological aspects of functional limitations during movement and posture]. Rehabilitácia, 26, 136-144.

Bunc, V. (2006). Zvláštnosti kondiční př́ipravy žen [Special fitness training for women]. In I. Čechovská, V. Bunc, \& V. Novotná (Eds.), Fit programy pro ženy (pp. 9-23). Praha: Grada Publishing.

Bursová, M. (2005). Kompenzační cvičení [Compensation exercises]. Praha: Grada Publishing. 
Bursová, M., Votík, J., \& Zálabák, J. (2003). Kompenzačni cvičeni pro fotbalisty [Compensation exercise for soccer players]. Praha: Olympia.

Cingálková, M., Bunc, V., \& Cingálek, R. (2001). Kineziologický rozbor jako prostředek kodhalení svalových dysbalancí a prevence zranění u fotbalistů [Use of kinesiologic analysis in injury prevention of football players]. In H. Válková \& Z. Hanelová (Eds.), $2^{\text {nd }}$ International conference Movement and Health (p. 532). Olomouc: Univerzita Palackého.

Data Input. (2004). Manual NUTRI 4 - Multifrequency software for the determination of body water, body composition and nutritional status. Pöcking: Author.

De Castro, J. V., Machado, K. C., Scaramussa, K., \& Gomes, J. L. E. (2013). Incidence of decreased hip range of motion in youth soccer players and response to a stretching program: A randomized clinical trial. Journal of Sport Rehabilitation, 22, 100-107.

Dittmar, M. (2003). Reliability and variability of bioimpedance measures in normal adults: Effects of age, gender, and body mass. American Journal of Physical Anthropology, 122, 361-370.

Dovalil, J., Choutka, M., Svoboda, B., Hošek, V., Perič, T., Potměšil, J., ... Bunc, V. (2002). Výkon a trénink ve sportu [Performance and training in sport]. Praha: Olympia.

Fajfer, Z. (1990). Koordinační (obratnostní) schopnosti, pohyblivost (strečink) v systému hráče fotbalu [Coordination (dexterity) capability, flexibility (stretching) in the system of soccer players]. Brno: ČFS.

Ferguson, C. J. (2009). An effect size primer: A guide for clinicians and researchers. Professional psychology: Research and Practice, 40, 532-538.

Friery, K. (2008). Incidence of injury and disease among former athletes: A review. Journal of Exercise Physiology Online, 11(2), 26-45.

Gúth, A. (1994). Propedeutika v rehabilitácii [Propedeutics in rehabilitation]. Bratislava: Liečreh.

Houglum, P. A. (2001). Therapeutic exercises for athletic injuries. Champaign, IL: Human Kinetics.

Janda, V. (1981). Vyšsetrování hybnosti [Investigation of the movement]. Praha: Avicenum.

Janda, V. (1996). Funkční svalový test [Functional muscle's test]. Praha: Grada.

Janda, V., \& Pavlů, D. (1993). Goniometrie [Goniometry]. Brno: IPVPZ.

Janura, M., \& Zahálka, F. (2004). Kinematická analýza pohybu člověka [Kinematic analysis of human movement]. Olomouc: Univerzita Palackého.

Kovacs, M. S. (2006). The argument against static stretching before sport and physical activity. Athletic Therapy Today, $11(3), 6-8$.

Kutáč, P., \& Gajda, V. (2006). Kvalita hybných funkcí $\mathrm{u}$ hráčů kopané ve vztahu $\mathrm{k}$ jejich výkonnosti [The quality of motional functions of football players in relation to their performance]. Česká antropologie, 56(1), 85-87.

Kyle, U. G., Bosaeus, I., De Lorenzo, A. D., Deurenberg, P., Elia, M., Manuel Gomez, J., ... ESPEN. (2004). Bioelectrical impedance analysis - part II: Utilization in clinical practice. Clinical Nutrition, 23, 1430-1453.

Lewit, K. (1996). Manipulační léčba [Manipulation therapy]. Leipzig: Česká lékařská společnost Jana Evangelisty Purkyně.

Little, T., \& Williams, A. G. (2006). Effects of differential stretching protocols during warm-ups on high-speed motor capacities in professional soccer players. Journal of Strength and Conditioning Research, 20, 203-207.
Magnusson, P., \& Renström, P. (2006). The European college of sports sciences position statement: The role of stretching exercises in sports. European Journal of Sport Science, 6, 87-91.

Malátová, R., \& Matějková, P. (2011). Svalové dysbalance u hráču fotbalu ve věku 21-33 let [The muscles imbalances of footballers and their compensation]. Studia Kinanthropologica, 12, 35-39.

Morse, D. T. (1999). Minisize2: A computer program for determining effect size and minimum sample for statistical significance for univariate, multivariate, and nonparametric tests. Educational and Psychological Measurement, 59, 518-531.

Nédélec, M., McCall, A., Carling, C., Legall, F., Berthoin, S., \& Dupont, G. (2012). Recovery in soccer: Part I - postmatch fatigue and time course of recovery. Sports Medicine, 42, 997-1015.

Nováková, H. (1994). Význam flexibility u dětí a mládeže [The importance of flexibility in children and youth]. Tělesná výchova a sport mládeže, 60(5), 36-39.

Peterson, L., Renström, P., \& Grana, W. A. (1986). Sports injuries: Their prevention and treatment. Sant Louis: Mosby Year Book.

Rogan, S., Wüst, D., Schwitter, T., \& Schmidtbleicher, D. (2013). Static stretching of the hamstring muscle for injury prevention in football codes: A systematic review. Asian Journal of Sports Medicine, 4(1), 1-9.

Rychlíková, E. (2002). Funkční poruchy kloubů končetin: diagnostika a léça [Functional disorders of the joints of limbs: diagnostic and treatment]. Praha: Grada.

Šámková, P., \& Votík, J. (2010). Svalové dysbalance a možnosti jejich prevence a korekce u hráčů žákovské kategorie FC Viktoria Plzeň [Muscle imbalances and possibility of their prevention in case of players of student category of FC Viktoria Plzeň]. Studia Kinanthropologica, 11, 101-107.

Theodorou, I., Galazoulas, C., Zakas, N., Vergou, A., \& Vamvakoudis, E. (2005). The effect of stretching duration on the flexibility of lower extremities in junior soccer players. Physical Training, 1(1), 1.

Trojan, S., Druga, R., Pfeiffer, J., \& Votava, J. (1996). Fyziologie a léčebná rehabilitace motoriky člověka [Physiology and rehabilitation of the human motorics]. Praha: Grada.

Véle, F. (1997). Kineziologie pro klinickou praxi [Kinesiology for clinical practice]. Praha: Grada.

Volpi, P., Melegati, G., Tornese, D., \& Bandi, M. (2004). Muscle strains in soccer: A five year survey of an Italian major league team. Knee Surgery, Sports Traumatology, Arthroscopy, 12, 482-485.

Wong, P. L., \& Hong, Y. (2005). Soccer injury in the lower extremities. British Journal of Sports Medicine, 39, 473-482.

Yuktasir, B., \& Kaya, F. (2009). Investigation into the longterm effects of static and PNF stretching exercises on range of motion and jump performance. Journal of Bodywork and Movement Therapies, 13, 11-21.

Zakas, A., Doganis, G., Galazoulas, C., \& Vamvakoudis, E. (2006). Effect of acute static stretching duration on isokinetic peak torque in pubescent soccer players. Pediatric Exercise Science, 18, 252-261.

Zakas, A., Grammatikopoulou, M. G., Zakas, N., Zahariadis, P., \& Vamvakoudis, E. (2006). The effect of active warm-up and stretching on the flexibility of adolescent soccer players. Journal of Sports Medicine \& Physical Fitness, 46, 57-61. 